\title{
3
}

\section{'Boyd's Blacks': Labour and the Making of Settler Lands in Australia and the Pacific}

\author{
Tracey Banivanua Mar
}

Tracey Banivanua Mar's untimely death on 19 August 2017 meant that she never completed this chapter. The version here is an edited draft of the paper that she circulated in the Labour Lines Workshop held at Deakin University in June 2017. Banivanua Mar wrote in regard to that draft: 'NB as per "Labour Lines" suggestions, this paper is still in draft form for the purpose of workshopping. This paper and research has been funded by the Australian Research Council, and is part of the Discovery Project "Land and Colonial Cultures" (DP 120104928).' Where possible, Tracey's own words have been retained and only minor amendments and additional information gleaned from her notes have been made by Kalissa Alexeyeff, Lucy Davies and Alan Lester. We hope that researchers will be genuinely inspired by the paper's insights into the transnational complexity of the early colonial labour trade, the global and intersecting reach of land, labour and commerce, and, most importantly, Pacific Islander experiences of mobility during the early nineteenth century.

In the early evening of a Tuesday night in October 1847, the settlement of Parramatta on the outskirts of Sydney, New South Wales, was 'thrown into considerable alarm and excitement' as a group of around 20 or 30 men and boys recently arrived from what was then called the New Hebrides briefly took over the streets. These 'blackfellows, with red hair', marched into Parramatta, shouting and gesturing as they ignored fences and passed 
through doors marking the private property of estate owners. After trying and failing to board a nearby steamer, the Emu, they eventually settled together 'under a portico at the rear of the military barracks' covered only by a tarpaulin. The following morning, 'with a hideous shout', they rose and continued to march in the direction of Sydney. ${ }^{1}$ The Sydney press was unequivocal in reporting this Parramatta scene as one in which violence and an 'outrage of a most serious nature' would have been inevitable without the presence of an ever-watchful police force. No 'outrage was perpetrated' and the Hunter River press reported that this was due to the police having 'acted legally, wisely and judiciously' in closely watching the men whose 'yellings and hootings and violence of gesture', and whose water bottles suspended on 'formidable' sticks, were a clear threat to 'Parramattonians'. The next day, as the men and boys made their way to Sydney, they were watched, followed and reported on, with the Maitland Mercury later observing that such surveillance had undoubtedly preserved 'life and property'.

The New Hebrideans, or Ni-Vanuatu, who marched on Parramatta had probably recently arrived in New South Wales on board either the Portenia or Velocity; both vessels had docked in Sydney loaded with around 100 men and boys from the New Hebrides who were under contract to work for a period of indenture for local pastoralist Benjamin Boyd. ${ }^{3}$ Their arrival in Sydney, and that six months earlier of another 100 men and boys aged between 14 and 25, is a well-told story. They were, historians have reported, the first incarnation of what would eventually be a brutal 40-year trade in indentured labour from the Pacific, one that would found and enrich Queensland's sugar industry from $1868 .{ }^{4}$ Fewer have wondered who these men were, what their often fatal experience was, and

1 'The New Hebrideans', The Maitland Mercury and Hunter River General Advertiser, 16 October $1847,2$.

2 'The New Hebrideans', The Maitland Mercury and Hunter River General Advertiser, 16 October 1847,2 .

3 'Shipping Intelligence', The Australian, 22 April 1847, 2; 'Shipping Intelligence', The Australian, 28 September 1847, 2; 'Shipping Intelligence', Sydney Chronicle, 19 October 1847, 2. There is some evidence to suggest that Boyd's recruiters also picked up men from Lifou, Loyalty Islands and other adjacent islands.

4 Banivanua Mar, Violence and Colonial Dialogue, 12. See also Saunders, 'The Worker's Paradox'; Saunders, 'The Black Scourge'; Saunders, 'Troublesome Servants'; Corris, "Blackbirding" in New Guinea'; Corris, Passage, Port and Plantation; Corris, "White Australia” in Action'; Moore, Kanaka; Moore, "Whips and Rum Swizzles"'; Graves, Cane and Labour; Graves, 'Colonialism'; Graves, 'Crisis and Change'; Graves, 'Trucks and Gifts'; Shlomowitz, 'Epidemiology'; Shlomowitz, 'Indentured Melanesians'; Shlomowitz, 'Markets for Indentured'; Shlomowitz, 'Mortality'. 
what their presence in New South Wales in the 1840s might tell us about historical and even contemporary patterns of labour and colonisation in and around the Pacific. ${ }^{5}$

The presence of Māori, Polynesians and, increasingly, Melanesians was commonplace at cosmopolitan ports from the early nineteenth century. By the 1840s, Port Jackson was a central node in an extensive Pacific maritime world. A growing body of scholarly work explores the global reach of this network. Lynette Russell, most notably, has shown how Indigenous Australian sailors and whalers were highly mobile from the late eighteenth century, working throughout the Pacific and beyond since the turn of that century. ${ }^{6}$ Other historians have traced Māori and Pacific journeying and historic connections and its shaping of Aotearoa/New Zealand history; however, the extent of Australia's Pacific history remains to be told in its entirety. ${ }^{7}$

In focusing more closely on the experiences of these men and boys in New South Wales and the Port Phillip Protectorate, I reflect on how their stories, important in their own right as testimonials, are also manifestations of interdependent structures of colonisation. In particular, the event of their arrival and presence in New South Wales brings into focus the contingencies through which 'land'—as a British imperial project through which Indigenous spaces were partitioned, converted into property and brought violently into markets of mass production and consumption-was being made through the harnessing, regulation, extraction and eradication of Indigenous bodies and systems of both ownership and industry.

5 Banivanua Mar, Decolonisation and the Pacific; Chappell, Double Ghosts; Shineberg, The People Trade; Shineberg, They Came for Sandalwood.

6 Russell, Roving Mariners.

7 Banivanua Mar, Decolonisation and the Pacific; Banivanua Mar, 'Shadowing'; O'Brien, The Pacific Muse; Salesa, Racial Crossings; Salmond, Between Worlds; Salmond, Two Worlds; Somerville, 'Living on New Zealand Street'; Standfield, Race and Identity; Standfield, 'The Parramatta Maori'; Standfield, 'Mobility, Reciprocal Relationships'. As Banivanua Mar notes, these maritime networks linked to a wider web of imperial discourse that connected trade and labour, but also efforts to reshape Indigenous bodies and souls. Administrators, such as Samuel Marsden, experimented with imparting literacy, language and religion differentially to both Aboriginal and Maori youth at Parramatta. Banivanua Mar, Decolonisation and the Pacific, 52-53. 


\section{Boyd's Experiment}

The Ni-Vanuatu boys and men who arrived in New South Wales in October 1847 belonged to 'Missa Boyd' ${ }^{8}$ Benjamin Boyd was a merchant banker who was keen to try settler colonial experiments, steeped in the experimental zeal of the day, for transforming wasted 'native' land and bodies into productive capital. Boyd entertained Wakefieldian fantasies of socially and spatially engineered settler colonies. First, in the islands of the Pacific, he sought to establish a minor colony that might 'later become a portion of the southern lands of the British Empire'. 'Later, in the colony of New South Wales, he envisaged the establishment of self-sufficient villages, comprising:

One to two hundred cottages - every such cottage having attached to it a well-fenced garden — and every such village having a church, a school, and houses for a clergyman and schoolmaster. ${ }^{10}$

Fuelled by stories of economic opportunities in the young colony of New South Wales, Boyd on sold prospects of handsome return to investors of the Royal Bank of Australia (formed in London in 1839), and was made the bank's director in the colony. With the bank's capital at his disposal, and his own network of commercial assets, Boyd took the colony by storm, establishing a pastoral empire after his arrival on 15 June 1842. Within two years of his arrival he had acquired a total of 426,000 acres, making him the largest landholder after the Crown. ${ }^{11}$ From this vast and well-watered swathe of land along the Riverina and the Monaro plateau in New South Wales, cattle and sheep were funnelled into what was to become a pivotal township and seaport. He set up operations in Twofold Bay, building a hotel, church, vegetable gardens and orchards and dwellings for his staff. Boyd, who owned a fleet of vessels, engaged in freighting to overseas markets and whaling. ${ }^{12}$ He founded a port, jetty and a lighthouse and furnaces for rendering cattle and sheep for tallow. He named this settlement Boydtown.

8 'Yass', The Sydney Morning Herald, 27 October 1847, 3; 'Shipping Intelligence (From The Sydney Morning Herald): Yass', The Maitland Mercury and Hunter River General Advertiser, 30 October 1847, 2-3.

9 Wellings, Benjamin Boyd in Australia, 2-4.

10 Boyd, A Letter to His Excellency, 4.

11 Wellings, Benjamin Boyd in Australia, 5. During the 1840s, the Royal Bank, or Boyd \& Robinson, had more than 160,000 sheep and controlled over 2,500,000 acres (1,011,715 ha) in the Monaro and Riverina. Walsh, 'Boyd, Benjamin'.

12 Wellings, Benjamin Boyd in Australia, 5-8. 
Boyd's pastoral empire was also an empire of labour, having around 800 men constantly employed as shepherds and stockmen on his estates, and labourers and crew as part of his shipping interests. He recruited labour from across the globe including from Britain, Europe and the Pacific Islands, as well as Aboriginal people and former African-American slaves. ${ }^{13}$ As the chairman of the powerful Pastoralists' Association, Boyd lobbied for land and labour reform. Indeed, he saw land and labour as existing in an inseparable bind-the question was not about availability, but affordability in the context of making a profit. ${ }^{14} \mathrm{He}$ continually badgered government for support with labour costs. When giving evidence on 27 September 1843 to the Select Committee on Immigration, he despaired the fate of the colony 'unless we have cheap labour, and can bring the wages of the shepherd ... to [10 pounds] a year with rations' of meat and flour, but not tea or sugar. ${ }^{15}$ Boyd then began promoting the idea of importing labour from sister colonies such as Van Diemen's Land or Moreton Bay. In a letter to Sir William Denison, lieutenant-governor of Van Diemen's Land, Boyd argued that transpacific passage was a heavy expense to the colony and offered the solution that convicts with tickets of leave in Van Diemen's Land be granted pardons conditional on them going to New South Wales to work on the 'vast labour-fields'. ${ }^{16}$ Unfortunately for Boyd, Dension did not consider this scheme attractive.

In the context of pastoralists coming to terms with the end of their access to cost-neutral transported British and convict labour, Boyd developed his ideas about labour importation by extending his employment of Pacific Islanders already working in his whaling and sandalwood ventures. In 1847 , he imported nearly $200 \mathrm{Ni}$-Vanuatu on periods of indenture. As an expansion of an existing set of relationships in the islands, the people or communities he recruited from would have had a working knowledge of the British and Australian thirst for labour. However, agricultural and indentured labour was on a scale that dwarfed demands for whaling and sandalwood extraction.

The language of 'importation' rather than immigration, as adopted by Boyd, framed the commodification and proprietorship of employment and the reductive placement of Islanders' bodies and extracted labour in a language of economic units, and was a precursor to the Australia-Pacific

13 Walsh, 'Boyd, Benjamin'; 'Legislation in New South Wales (From the London Telegraph,

March 23 ${ }^{\text {rd }}$ ', The Port Phillip Patriot and Morning Advertiser, 7 August 1848, 4.

14 Boyd, A Letter to His Excellency.

15 Walsh, 'Boyd, Benjamin'.

16 Boyd, A Letter to His Excellency. 
indentured labour trade of 1868-1906. Here we note a stark distinction from the widespread use of forced Aboriginal labour in the pastoral/ agricultural industries. In Queensland, the use of Pacific Islander labour would be explicitly legalised, quantified and regulated as an industry, and would stand as an acknowledged symbol of settler expedience and success in neatly and visibly converting 'waste' Indigenous land into productive settler property. By contrast, the use of Indigenous peoples' labour, though widespread and normalised, would remain hidden and ignored, indicative as it was of the dependence of settlers on Indigenous knowledge, skills and labour even as they pursued colonial fantasies of empty landscapes converted by Anglo-Saxon industry into 'productive property'.

\section{Ni-Vanuatu Experience, April-November 1847}

On arrival in New South Wales, labourers were conveyed to the hastily constructed and ludicrously grand Boydtown near current-day Eden. Boydtown sat on Twofold Bay, where both deep-sea and onshore whaling industries flourished. The beaches, when Ni-Vanuatu labourers arrived, would have been covered in either whale carcasses or the 'enormous bones of whales bleaching in the weather'. ${ }^{17}$ On still days, a thick haze of smoke would have settled over the bay and half-built town as enormous vats and cauldrons simmered over open fires extracting the blubber from stinking whale meat. Thousands of sheep and cattle were boiled down for tallow as a direct result, Boyd frequently claimed, of a paucity of labour to tend to them. ${ }^{18}$ For newly arrived New Hebrideans, the smell and sight of this gruesome industry must have been a brutal introduction to the colony. From here they were then expected to walk to stations on the Monaro tablelands and Riverina on Yorta Yorta country. The remoteness of shepherding would have characterised their experience of work in New South Wales. There was also evidence that the new arrivals were assaulted 'in a most savage manner' by local stockmen—-treatment that Protectors of Aborigines appointed to the neighbouring Port Phillip District were enjoined to intercede against on behalf of workers. ${ }^{19}$

17 Wellings, Benjamin Boyd in Australia, 42-43.

18 Boyd, A Letter to His Excellency; Wellings, Benjamin Boyd in Australia, 16.

19 PROV VPRS 11/PO, Unit 10, 'Unregistered Inward Correspondence to the Chief Protector of Aborigines Regarding South Sea Islanders Imported by Mr. Boyd W. Thomas (Assistant Protector, Westernport District)', contains letter to the Chief Protector from W. Thomas, Melbourne, 30 October 1847; 'Local and Colonial Intelligence: BOYD'S SAVAGES and SOUTH SEA ISLANDERS', Geelong Advertiser, 2 November 1847, 1. 
Boyd did not wait for government permission to import this 'black' labour and the settler response was predictable. Those in favour of indenture lamented the need for pastoralists to resort to barbarous and non-Anglo-Saxon labour. Colonists, it was said, would never import foreigners 'much less savages and heathens' if they could bring in their own countrymen or draw on former convict labour. It was only out of urgency, they argued, that they had to send to India for 'Coolies' or to the Pacific Islands, which 'literally swarm with human beings'. ${ }^{20}$ Those against importation described it as incipient slavery. Most responses were deeply racialised, highlighting black savagery signified most clearly by cannibalism. ${ }^{21}$ The Sporting Reviewer christened Boyd as the 'King of the Cannibal Islands', who, in an accompanying ditty, unsurprisingly met an unfortunate end (see Figure 3.1). ${ }^{22}$

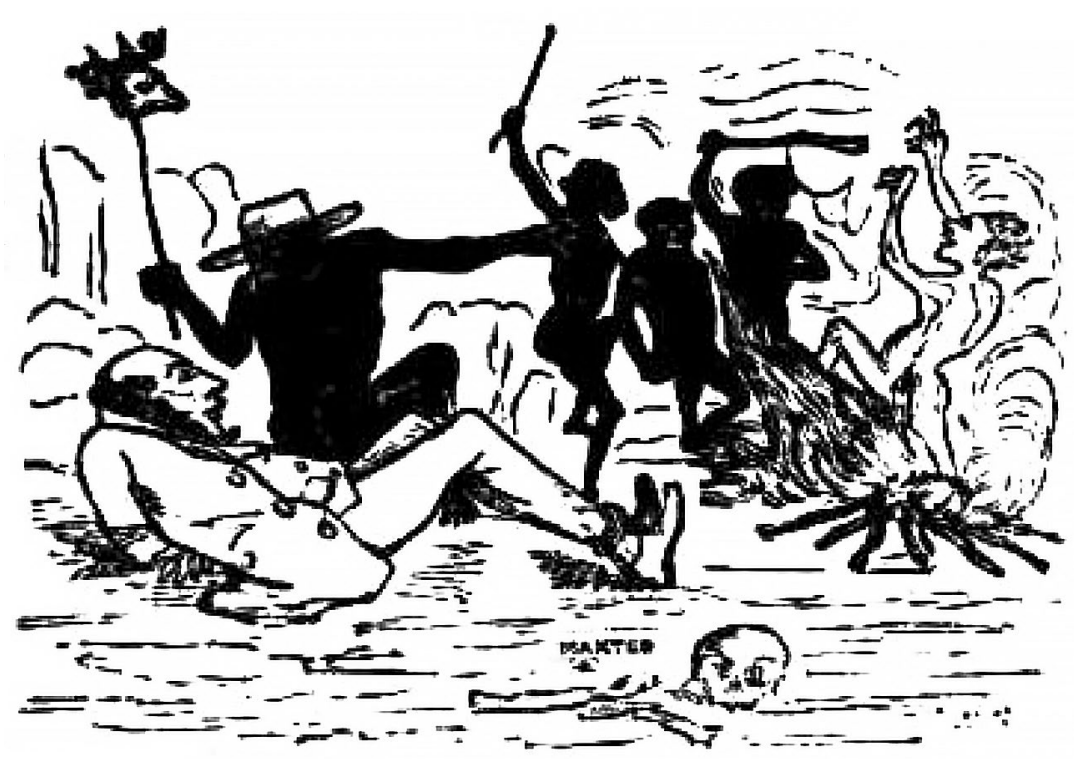

Figure 3.1: Cartoon depiction of Boyd as 'King of the Cannibal Islands'. Source: Sydney and Sporting Reviewer, 1 May 1847, 3.

20 'Immigration From Polynesia', The Sydney Morning Herald, 23 April 1847, 2. (Emphasis added.) 21 'Local and Colonial Intelligence: BOYD'S SAVAGES and SOUTH SEA ISLANDERS', Geelong Advertiser, 2 November 1847, 1. See also Banivanua Mar, 'Performing Cannibalism'; Banivanua Mar, 'Cannibalism and Colonialism'; Banivanua Mar, 'A Thousand Miles of Cannibal Lands'; Barker, Hulme and Iversen, Cannibalism.

22 'Gallery of Commicalities No. II. KING OF THE CANNIBAL ISLANDS', Bell's Life in Sydney and Sporting Reviewer, 1 May 1847, 3. 
The cannibalism trope persistently framed responses to the Islanders' and Boyd's endeavours:

\author{
A New Hebridean Love Song \\ Wallaloo! Wallaloo!
}

Love white man, and eat him too! Stranger white, but that's no matter, Brown man fat, but white man fatter! Put him on hot stone, and bake him,

Crisp and crackling soon we'll make him: Round and round the dainty goes,

Eat his fingers—eat his toes, His body shall our palate tickle,

Then we'll put his head in pickle! CHORUS.

On the white man dine and sup, Whet your teeth and eat him up! ${ }^{123}$

Concerns about cannibalistic instincts intersected with concerns about the racial composition of the future population. Fear of miscegenation and being 'overwhelmed' by these swarming hoards underlined much commentary, as the Maitland Mercury reported of Boyd's workers:

As a horde of savage cannibals, we cannot regard them otherwise than with loathing and abhorrence. Yet these are people that must be inevitably poured in upon us, as our demands for labour increase, and those who have raised a clamorous opposition to the introduction of British convicts into this colony once more, must be content hereafter to see our pastures filled, not with European Christians, but with cannibals, from their last disgusting banquet - with the flesh of their fellow-creatures hardly digested within them-and almost carrying about with them the repulsive odour of this unnatural food, which they have recently devoured. Then shall we find our fears excited, not for our properties, nor our morals, but for our lives. ${ }^{24}$

This fear and ridicule was echoed in parliamentary debate following Boyd's first shipment of labourers from the New Hebrides. Concern was raised about the nature of the 'importation', referring to it as 'an incipient slave trade, at variance with the spirit, if not the letter, of the British statute levelled at the traffic'. Questions about consent were also aired: 'those

23 'A New Hebridean Song', Bell's Life in Sydney and Sporting Reviewer, 6 November 1847, 4.

24 'The Recent Experiment In Immigration', Maitland Mercury, 28 April 1847, 2. 
who were imported here, under the semblance of contracts were people of the most brutal ignorance, totally incapable of understanding the most ordinary matters of civilized life'. ${ }^{25}$ The New South Wales Government refused to create a legal mechanism for the use of indentured labour generally and from the Pacific Islands specifically, amending the Masters and Servants Act 1847 to include Section 15:

Nothing in this or the said recited Act contained shall be deemed or construed to apply to any native of any savage or uncivilized tribe inhabiting any Island or Country in the Pacific Ocean or elsewhere. ${ }^{26}$

When a second shipload from the New Hebrides of 54 men and three women arrived at Twofold Bay on 17 October 1847, Boyd refused responsibility for them, as the contracts they had signed in the New Hebrides had been rendered null and void by the Masters and Servants Act. Boyd would go on to blame the New South Wales Government for the failure of his labour experiment and the suffering of Ni-Vanuatu, as these 'children of nature' were too wild and unreliable to undertake 'the more sophisticated prospects' that were opened before them; that is, a legal right to accept and to terminate employment. ${ }^{27}$ Many sought alternative work or passage home. The surveillance of these freely moving 'blacks' was reported in detail and concern was raised about their near nakedness and 'formidable sticks' in Parramatta. ${ }^{28}$

At the same time, workers from the first shipment left Boyd's stations and intelligence had them in Yass around 25 October on the way to see the governor and 'Missa Boyd'. The press took great delight in speculating about whether they were going to eat them both. ${ }^{29}$ Others, who had been employed along the Murray River, 'bolted' to Melbourne, arriving on

25 'Legislative Council. FRIDAY, OCTOBER 1', Sydney Chronicle, 2 October 1847, 2.

26 Masters and Servants Act 1847 (NSW) No 9a. No. IX., 16 August 1847, 'An Act to Amend an Act Intituled "An Act to Amend and Consolidate the Laws between Masters and Servants in New South Wales", accessed 13 June 2018, classic.austlii.edu.au/au/legis/nsw/num_act/masa1847n9262/, Section 15. See earlier debates about Indian indenture. Cullen, 'Empire, Indian Indentured Labour'; Saunders, Indentured Labour.

27 Walsh, 'Boyd, Benjamin'; Boyd, A Letter to His Excellency, 16.

28 'The New Hebrideans', The Maitland Mercury and Hunter River General Advertiser, 16 October $1847,2$.

29 'Shipping Intelligence', Sydney Chronicle, 19 October 1847, 2; 'Yass', The Sydney Morning Herald, 27 October 1847, 3; 'Shipping Intelligence (From The Sydney Morning Herald): Yass', The Maitland Mercury and Hunter River General Advertiser, 30 October 1847, 2-3. 
2 November, causing alarm in Geelong as they passed through 'in full march to Melbourne' in protest against their treatment and in pursuit of rides home. ${ }^{30}$

Those stranded in Sydney were reported as working around the harbour on boats transporting goods. 'Boyd's blacks', as they were still known, appeared in the colonial record primarily in coronial inquests, as they were engaged in body retrieval from water accidents and suicides. ${ }^{31}$ Their swimming and diving abilities were also noted in their attempts to board vessels thought to be travelling to the Pacific, the most tragic of which was recorded in the press report of an inquest into the discovery of 'the body of a black man, name unknown'. Some of 'Boyd's blacks' had swum out to his brig, which was lying about 2.5 miles from Boyd's premises, including the victim. However, 'the master of the Portenia would not allow the men on board, and they swam back', one drowning in the process. The jury stated that Boyd should have attended the inquest to:

Give evidence of what kind of treatment this man had received since his arrival in the country and that it was not-ill-treatment or starvation that induced this unfortunate savage to act in the way which ultimately led to his death. ${ }^{32}$

The missionary ship Arch D'Alliance was reported as landing 'the whole of the natives taken from Sydney (known as Boyd's blacks)' on one of the 'Royalty Islands' (presumably Loyalty Islands, present-day New Caledonia) in October $1848 .{ }^{33}$

30 'Local Intelligence', The Port Phillip Patriot and Morning Advertiser, 26 October 1847, 2; 'Local and Colonial Intelligence: BOYD'S SAVAGES and SOUTH SEA ISLANDERS', Geelong Advertiser, 2 November 1847, 1; 'Port Phillip', The Moreton Bay Courier, 20 November 1847, 4.

31 'Coroner's Inquest', The Sydney Morning Herald, 20 December 1847, 2; 'Sydney News', The Maitland Mercury and Hunter River General Advertiser, 22 December 1847, 4; 'Labor in the Colonies', The Australian, 4 February 1848, 3; 'Local Intelligence', Bell's Life in Sydney and Sporting Reviewer, 1 April 1848, 2.

32 'Domestic Intelligence', Sydney Chronicle, 2 November 1847, 3.

33 Press reports on Ni-Vanuatu divers and coronial inquests, 1847-48. On the landing of 'the whole of the natives taken from Sydney (known as Boyd's blacks)' by the missionary ship Arch d'Alliance at the 'Royalty Islands', see 'Collision Between a Missionary Ship and the Natives of New Guinea', Geelong Advertiser, 4 November 1848, 1. See also Banivanua Mar, Decolonisation and the Pacific; Chappell, Double Ghosts. 
By 1849, Boyd was bankrupt, operations in Twofold Bay had ceased and the 'whole venture so brilliantly launched yet so completely wrecked'. ${ }^{34}$ He sailed on his yacht, the Wanderer, to the Californian goldfields on 26 October and, upon failing to make his fortune there, returned to his idea of the creation of a miniature republic or confederation upon one of the islands of the Pacific. He arrived in Guadacanal in the Solomon Islands in 1851 but went missing on a duck-shooting trip on his second day. The surviving remnants of his Australian entrepreneurial dreams are the extravagant buildings of Boydtown, including 'Boyd's Folly' a partially constructed and huge tower for whale spotting, the Ben Boyd National Park established in 1971 and a smattering of roads named in his honour. While Boyd's life is commemorated, the lives and deaths of the Ni-Vanuatu labourers are largely invisible in Australian history and national projects of memorialisation.

\section{'Boyd's Blacks', Land and Extraction in Settler Colonies}

The stories of the 200 or so Ni-Vanuatu brought to New South Wales and the Port Phillip District in the 1840 s are virtually impossible to document beyond the feigned outrage of settlers and pastoralists, whose keen observations were focused less on the experiences of the Ni-Vanuatu men and boys, and more on the longer-term outcomes for a colony desperate for free labour. They remain unnamed and brutalised in the archival record, as they were routinely positioned as tools for an ulterior purpose by the colonial press, parliament and colonial speculators and business interests.

Historians have been accustomed to nationalising the history of indentured and forced labour in the Pacific, partitioning trade between Queensland, Peru, Fiji and France, for example. ${ }^{35}$ In some ways, this makes sense, as each national labour trade was governed by distinct legislation that had distinct effects on Islander communities, each country had discrete land

34 Wellings, Benjamin Boyd in Australia, 4-8.

35 Banivanua Mar, Violence and Colonial Dialogue; Corris, 'Blackbirding in New Guinea'; Corris, Passage, Port and Plantation; Maude, Slavers in Paradise; Moore, 'The Counter Culture of Survival'; Moore, Kanaka: A History; Moore, 'Kanakas, Kidnapping and Slavery'; Moore, 'The Mackay Racecourse Riot'; Moore, "Me Blind Drunk"; Moore, "Whips and Rum Swizzles”; Shineberg, The People Trade; Shineberg, They Came for Sandalwood. 
and labour needs, and each adopted apparently vastly different formal and informal colonial structures. On closer inspection, destination sites throughout the nineteenth century are only clearly colonies of settlement or extraction in hindsight. Pastoralists, settlers and plantation owners shared a common intent, whether driven by greed or ideology, of wanting to convert Indigenous social, economic and spiritual spaces-configured as wild and native wastes-into legally owned, economically productive, spatially contained and 'settled' land.

This segmentation of the Pacific labour trade is underpinned by a deeply imperial perspective, one governed by the constrictions and surveillance that accompanied, organised and legalised this trade. It does not necessarily reflect the lived experiences in the islands. Islander communities serviced multiple trades-Queensland, British, French and American-and were delivered for labour in multiple industries ranging from sugar, cotton and copra monocultures to mining or domestic labour. For example, on Tanna in 1847, Islanders would have been approached by sandalwood traders, missionaries, plantation and pastoral interests, and labour vessels 'recruiting' for numerous destination sites ranging from Queensland to Hawai' $i$. Across the course of a working life, individual labourers could engage in various trades and be subjected to varying levels of violence and coercion. ${ }^{36}$

Viewed in isolation, Boyd's experiment in New South Wales in the 1840s appears as a discrete failure. However, if we view the extraction of labour in the Pacific not in isolation, but instead in terms of a spatial and temporal continuum in which Boyd merely refocused his existing uses of Islander labour from maritime to agricultural pursuits, we gain a number of key insights. First, it points to the need for more nuanced understandings of the relationship between consent and coercion. As the desertion of Boyd's labourers and the choices facing Islanders shows, recruiters such as Boyd were dealing with communities that could be assertive about their own interests, even if the individuals 'recruited' were not necessarily consenting individuals. Second, and despite the faltering nature of Boyd's own entrepreneurialism, we need to be aware of the structural or slow violence that presented him with opportunities for personal gain in the newly colonised Pacific, and that underpinned formal, informal and decolonised imperialism, and its continuity.

36 See, for example, Peter Wien and others in 1906 Royal Commission Minutes of Evidence, cited in Banivanua Mar, Decolonisation and the Pacific, 71-73. 
Together, these insights offer a deeper understanding of the role that Islanders played as 'imported', rather than immigrant, labour throughout the imperial Pacific basin. As active agents within a new world of differentially racialised opportunity and constraint, they created 'labour lines', interweaving fates and creating entangled relationships of contingency that manifested new Oceanias.

Paying attention to the lived experience of Pacific Islanders caught up in the industrial extraction of labour during the colonial period is significant for its own sake. It partly recuperates histories and genealogies shattered and dispersed by the deeply dehumanising history of labour trading in and around the Pacific. At the same time, tracing the interconnectivity of labour lines in and across the Pacific highlights an interconnectedness and interdependence that partially united Indigenous and Islander histories and experiences of labour mobility and autonomy. It shows that settler colonialism was not a neatly and hermetically sealed, autonomous structure, but one that was entwined with other colonial or imperial structures and reliant on contingencies located in offsite colonial projects. The 'settler complex' was 'transnational', somewhat unbounded and spatially expedient. It was an entire empire of what Patrick Wolfe might have considered pre-accumulated power, in which it was necessary to eradicate and replace not just Indigenous systems of land ownership, but Indigenous social economies more broadly. ${ }^{37}$

\section{Bibliography}

\section{Primary Sources}

Masters and Servants Act 1847 (NSW) No 9a. No. IX., 16 August 1847, 'An Act to Amend an Act Intituled "An Act to Amend and Consolidate the Laws between Masters and Servants in New South Wales"', accessed 13 June 2018, classic.austlii.edu.au/au/legis/nsw/num_act/masa1847n9262/.

PROV VPRS 11/PO, Unit 10. 'Unregistered Inward Correspondence to the Chief Protector of Aborigines Regarding South Sea Islanders Imported by Mr. Boyd W. Thomas (Assistant Protector, Westernport District)'.

37 Wolfe, Traces of History; Wolfe, The Settler Complex. 


\section{Secondary Sources}

Banivanua Mar, Tracey. 'Cannibalism and Colonialism: Charting Colonies and Frontiers in Nineteenth-Century Fiji'. Comparative Studies in Society and History 52, no. 2 (2010): 255-81. doi.org/10.1017/S0010417510000046.

- Decolonisation and the Pacific: Indigenous Globalisation and the Ends of Empire. Cambridge: Cambridge University Press, 2016.

—. 'Performing Cannibalism in the South Seas'. In Touring Pacific Cultures, edited by Kalissa Alexeyeff and John Taylor, 323-32. Canberra: ANU Press, 2016. doi.org/10.22459/TPC.12.2016.21.

- 'Shadowing Imperial Networks: Indigenous Mobility and Australia's Pacific Past'. Australian Historical Studies 46, no. 3 (2015): 340-55. doi.org/ 10.1080/1031461X.2015.1076012.

—. "'A Thousand Miles of Cannibal Lands": Imagining Away Genocide in the Re-Colonisation of West Papua'. Journal of Genocide Research 10, no. 4 (2008): 583-602. doi.org/10.1080/14623520802447743.

- Violence and Colonial Dialogue: The Australian-Pacific Indentured Labor Trade. Honolulu: University of Hawai'i Press, 2007.

Barker, Francis, Peter Hulme and Margaret Iversen, eds. Cannibalism and the Colonial World. Cambridge: Cambridge University Press, 1998.

Boyd, Benjamin. A Letter to His Excellency Sir William Denison, LieutenantGovernor of Van Diemen's Land, on the Expediency of Transferring the Unemployed Labor of that Colony to New South Wales, Benjamin Boyd. Sydney: E. Wolfe, 1847.

Chappell, David. Double Ghosts: Oceanian Voyagers on Euroamerican Ships. London, England: M. E. Sharpe, c. 1997.

Corris, Peter. “"Blackbirding” in New Guinea Waters, 1883-84'. Journal of Pacific History 3 (1968): 85-105. doi.org/10.1080/00223346808572126.

- Passage, Port and Plantation: A History of Solomon Islander Labour Migration, 1870-1914. Melbourne: Melbourne University Press, 1973.

_. "“White Australia” in Action: The Repatriation of Pacific Islanders from Queensland'. Historical Studies 15, no. 58 (1972): 237-50. doi.org/10.1080/ 10314617208595469.

Cullen, Co R. 'Empire, Indian Indentured Labour and the Colony: The Debate Over “Coolie” Labour in New South Wales, 1836-1838'. History Australia 9, no. 1 (2012): 84-109. doi.org/10.1080/14490854.2012.11668404. 
Graves, Adrian. Cane and Labour: The Political Economy of the Queensland Sugar Industry, 1862-1906. Edinburgh: Edinburgh University Press, 1993.

. 'Colonialism and Indentured Labour Migration in the Western Pacific, 1840-1915'. In Colonialism and Migration: Indentured Labour before and after Slavery, edited by P. C. Emmer, 237-59. Dordrecht: Martinus Nijhoff Publishers, 1986. doi.org/10.1007/978-94-009-4354-4_11.

—. 'Crisis and Change in the Queensland Sugar Industry, 1862-1906'. In Crisis and Change in the International Sugar Economy, 1860-1914, edited by Bill Albert and Adrian Graves, 261-80. Norwich and Edinburgh: ISC Press, 1984.

—. 'Trucks and Gifts: Melanesian Immigrants and the Trade Box System in Colonial Queensland'. Past and Present 101 (1983): 87-106. doi.org/10.1093/ past/101.1.87.

Maude, Henry Evans. Slavers in Paradise: The Peruvian Slave Trade in Polynesia, 1862-1864. Palo Alto, CA: Stanford University Press, 1981.

Moore, Clive. 'The Counterculture of Survival: Melanesians in the Mackay District of Queensland, 1865-1906'. In Plantation and Accommodation, edited by Brij Lal, Doug Munro and D. Beechert, 69-100. Honolulu: University of Hawai'i Press, 1993.

- Kanaka: A History of Melanesia Mackay. Port Moresby, Papua New Guinea: University of Papua New Guinea Press, 1985.

—_. 'Kanakas, Kidnapping and Slavery: Myths from the Nineteenth-Century Labour Trade and their Relevance to Australian Melanesians'. Kabar Serang 8, no. 9 (1981): 78-92.

—. 'The Mackay Racecourse Riot of 1883'. In Lectures in North Queensland History: Third Series. Townsville, Queensland: Department of History, James Cook University (1978): 181-96.

—. "Me Blind Drunk": Alcohol and Melanesians in the Mackay District, Queensland, 1867-1907'. In Health and Healing in Tropical Australia and Papua New Guinea, edited by Ray Macleod and Donald Denoon, 103-22. Townsville: James Cook University Press, 1991.

- " "Whips and Rum Swizzles"'. In Lectures in North Queensland History: Second Series, 119-34. Townsville, Queensland: Department of History, James Cook University, 1975.

O'Brien, Patricia. The Pacific Muse: Exotic Femininity and the Colonial Pacific. Seattle, WA: University of Washington Press, 2006.

Russell, Lynette. Roving Mariners: Australian Aboriginal Whalers and Sealers in the Southern Oceans, 1790-1870. New York: SUNY Press, 2012. 
Salesa, Damon. Racial Crossings: Race, Intermarriage, and the Victorian British Empire. Oxford: Oxford University Press, 2011. doi.org/10.1093/acprof:oso/ 9780199604159.001 .0001$.

Salmond, Anne. Between Worlds: Early Exchanges between Maori and Europeans, 1773-1815. Honolulu, HI: University of Hawai'i Press, 1997.

- Two Worlds: First Meetings Between Maori and Europeans, 1642-1772. Honolulu, HI: University of Hawai'i Press, 1992.

Saunders, Kay. “The Black Scourge”: Racial Responses Towards Melanesians in Colonial Queensland'. In Race Relations in Colonial Queensland: A History of Exclusion, Exploitation, and Extermination, edited by Ray Evans, Kay Saunders and Kathryn Cronin, 147-234. St Lucia, Queensland: University of Queensland Press, 1988. [1st ed. 1975.]

ed. Indentured Labour in the British Empire, 1834-1920. London: Croom Helm, 1984.

- "“Troublesome Servants": The Strategies of Resistance Employed by Melanesian Indentured Labourers on Plantations in Colonial Queensland'. Journal of Pacific History 14, no. 3 (1971): 168-83. doi. org/10.1080/00223347908572374.

. 'The Workers' Paradox: Indentured Labour in the Queensland Sugar Industry to 1920'. In Indentured Labour in the British Empire, 1834-1920, edited by Kay Saunders, 213-59. London: Croom Helm, 1984.

Shineberg, Dorothy. The People Trade: Pacific Island Laborers and New Caledonia, 1865-1930. Honolulu: Center for Pacific Island Studies, University of Hawai' i Press, 1999.

- They Came for Sandalwood: A Study of the Sandalwood Trade in the South West Pacific, 1830-1865. Melbourne: University of Melbourne Press, 1967.

Shlomowitz, Ralph. 'Epidemiology and the Pacific Labor Trade'. Journal of Interdisciplinary History 19 (1989): 585-610. doi.org/10.2307/203955.

- 'Indentured Melanesians in Queensland: A Statistical Investigation of Recruiting Voyages, 1871-1903'. Journal of Pacific History 16, no. 4 (1981): 203-07. doi.org/10.1080/00223348108572428.

- 'Markets for Indentured and Time-Expired Melanesian Labour in Queensland, 1863-1906'. Journal of Pacific History 11, no. 1 (1981): 66-88. doi.org/10.1080/00223348108572416.

'Mortality and the Pacific Labour Trade'. Journal of Pacific History 22, no.1 (1987): 34-55. doi.org/10.1080/00223348708572550. 
Somerville, Alice Te Punga. 'Living on New Zealand Street: Maori Presence in Parramatta'. Ethnohistory 61, no. 4 (2014): 655-69. doi.org/10.1215/ 00141801-2717813.

Standfield, Rachel. 'Mobility, Reciprocal Relationships and Early British Encounters in the North of New Zealand'. In Indigenous Mobilities: Across and Beyond the Antipodes, edited by Rachel Standfield, 57-77. Canberra: ANU Press and Aboriginal History, 2018. doi.org/10.22459/IM.06.2018.03.

—. 'The Parramatta Maori Seminary and the Education of Indigenous Peoples in Early Colonial New South Wales'. History of Education Review 41, no. 2 (2012): 119-28. doi.org/10.1108/08198691311269493.

- Race and Identity in the Tasman World, 1769-1840. London: Pickering and Chatto, 2012.

Walsh, G. P. 'Boyd, Benjamin (Ben), (1801-1851)'. Australian Dictionary of Biography, National Centre of Biography, The Australian National University, 1966, accessed 4 June 2018, adb.anu.edu.au/biography/boys-benjaminben-1815/text2075.

Wellings, Henry Percival. Benjamin Boyd in Australia: 1842-1849: Shipping Magnate: Merchant: Banker Pastoralist and Station Owner: Member of the Legislative Council: Town Planner: Whaler. Sydney: D.S. Ford, 1950.

Wolfe, Patrick, ed. The Settler Complex: Recuperating Binarism in Colonial Studies. Berkeley: University of California Press, 2016.

—. Traces of History: Elementary Structures of Race. London: Verso, 2016. doi.org/10.1111/1468-229X.12265.

\section{Newspapers}

The Australian

Bell's Life in Sydney and Sporting Reviewer

Geelong Advertiser

The Maitland Mercury

The Maitland Mercury and Hunter River General Advertiser

The Moreton Bay Courier

The Port Phillip Patriot and Morning Advertiser

Sydney Chronicle

The Sydney Morning Herald 
This text is taken from Labour Lines and Colonial Power: Indigenous and Pacific Islander Labour Mobility in Australia, edited by Victoria Stead and Jon Altman, published 2019 by ANU Press, The Australian National University, Canberra, Australia.

doi.org/10.22459/LLCP.2019.03 